\title{
KEANEKARAGAMAN PHYTOPLANKTON DI SITU BALONG KAMBANG DESA PASAWAHAN KECAMATAN PASAWAHAN KABUPATEN KUNINGAN
}

\author{
Nadea Novasaraseta ${ }^{1)}$, Zaenal Abidin ${ }^{2)}$, Edi Junaedi' ${ }^{2)}$ \\ ${ }^{1}$ Mahasiswa Program Studi Pendidikan Biologi FKIPU, niversitas Kuningan \\ Email: nadeanovasaraseta46@gmail.com \\ ${ }^{2}$ Dosen Program Studi Pendidikan Biologi FKIP, Universitas Kuningan \\ Email: zaenal.abidin@uniku.ac.id \\ Email: edi.junaedi@uniku.ac.id
}

APA Citation: Novasaraseta, N., Abidin, Z., \& Junaedi, E. (2018). Keanekaragaman Phytoplankton Di Situ Balong Kambang Desa Pasawahan Kecamatan Pasawahan Kabupaten Kuningan. Quagga: Jurnal Pendidikan dan Biologi, 10(1), 32-40. doi: 10.25134/quagga.v10i01.806.

\begin{abstract}
Abstrak: Phytoplankton dapat digunakan sebagai bioindikator kualitas air. Penelitian tentang Keanekaragaman phytoplankton di Situ Balong Kambang Desa Pasawahan Kecamatan Pasawahan Kabupaten Kuningan bertujuan untuk mengetahui keanekaragaman phytoplankton sebagai bioindikator kualitas air. Penentuan stasiun pengambilan sampel phytoplankton menggunakan metode sampling sistematis dan penghitungan populasi ikan dewa dengan menggunakan metode kuadran. Peneliti menetapkan 5 stasiun. Parameter fisika-kimia yang di ukur adalah kecepatan arus, intensitas cahaya, suhu, DO, BOD, dan pH. Data yang diperoleh kemudian dianalisis dalam indeks biologi, seperti indeks keanekaragaman, indeks dominansi, indeks keseragaman, dan indeks kelimpahan. Hasil identifikasi phytoplankton ditemukan 27 genus dari 4 divisi utama yaitu Chlorophyta (10 genus), Cyanophyta ( 3 genus), Bacillariophyta (12 genus), dan Cyanobacteria (2 genus). Indeks Keanekaragaman (H') berkisar antara 2,33 - 2,61 berarti komunitas biota dalam keadaan sedang. Kelimpahan phytoplankton $(N)$ berkisar antara 1191 sel/liter sampai 623 sel/liter yang tergolong rendah. Indeks Keseragaman (J) berkisar antara 0,69 - 0,76 yang berarti memiliki nilai keseragaman stabil. dan Indeks Dominansi berkisar antara 0,11 - 0,13 berarti dari semua spesies di stasiun tidak ada yang mendominansi. Hasil analisis regresi linier sederhana kelimpahan phytoplankton dengan kelimpahan ikan dewa tidak signifikan, begitupun dengan nilai parameter fisika-kimia dengan keanekaragaman phytoplankton karena nilai Fhit < Ftab.
\end{abstract}

Kata Kunci : Keanekaragaman Phytoplankton, Kualitas air, Indeks Biologi, Perairan Balong Kambang

\begin{abstract}
Phytoplankton can be used as a bioindicator of water quality. Research on the diversity of phytoplankton in Balong Kambang Situ, Pasawahan Village, Pasawahan Subdistrict, Kuningan Regency aims to determine the diversity of phytoplankton as bioindicators of water quality. Determination of phytoplankton sampling stations using the method of systematic sampling and calculation of deity fish populations using the quadrant method. The researcher set 5 stations. The physical-chemical parameters measured were current velocity, light intensity, temperature, DO, BOD, and pH. Data obtained were then analyzed in biological indices, such as diversity index, dominance index, uniformity index, and abundance index. The results of phytoplankton identification found 27 genera from 4 main divisions, namely Chlorophyta (10 genera), Cyanophyta (3 genera), Bacillariophyta (12 genera), and Cyanobacteria (2 genera). The Diversity Index $\left(H^{\prime}\right)$ ranges from $2.33-2.61$, meaning the community of biota is in a moderate state. The abundance of phytoplankton $(N)$ ranges from 1191 cells / liter to 623 cells / liter which is relatively low. The Uniformity Index (J) ranges from $0.69-0.76$ which means it has a stable uniformity value. and the Dominance Index ranged from $0.11-0.13$, meaning that none of the species at the station dominated. The results of simple linear regression analysis of the abundance of phytoplankton with the abundance of deity fish were not significant, as were the values of physicochemical parameters with diversity of phytoplankton due to the value of Fhit <Ftab.
\end{abstract}

Keywords: Phytoplankton diversity, water quality, biology index, Balong Kambang waters 
Quagga: Jurnal Pendidikan dan Biologi Volume 10, Nomor 1, Januari 2018

\section{PENDAHULUAN}

Kabupaten Kuningan memiliki beberapa mata air tawar yang berasal dari Gunung Ciremai kemudian di alirkan ke beberapa desa. Air tawar memiliki beberapa manfaat yang sangat besar bagi kebutuhan makhluk hidup. Ekosistem air tawar terdiri dari dua jenis yaitu perairan lotik dan perairan lentik. Perairan lotik termasuk kanal, air terjun, sungai dan anak sungai. Sistem lentik termasuk kolam, genangan air, waduk, danau dan ladang pertanian seperti sawah (Manickam et al. 2012).

Salah satu sumber air tawar yang dianggap relatif mudah dimanfaatkan oleh manusia, diantaranya berupa situ. Situ adalah bahasa sunda yang berarti danau. Danau merupakan wilayah tampungan air tawar yang sangat penting untuk kelestarian lingkungan. Terdapat komponen abiotik dan biotik (bentos, nekton, plankton, dan neuston) yang menyusun ekosistem danau yang akan saling berinteraksi dengan melalui arus energi dan daur hara (nutrient).

Situ merupakan suatu habitat berbagai jenis makhluk hidup selain ikan itu sendiri. Di dalamnya terdapat makhluk hidup lain yang menjadi makanan alami ikan. Makanan alami ikan diantaranya adalah plankton. Plankton adalah makhluk hidup (tumbuhan atau hewan) yang hidupnya mengapung, mengambang, atau melayang di dalam air yang kemampuan renangnya (kalaupun ada) sangat terbatas hingga selalu terbawa hanyut oleh arus. Istilah "plankton" diperkenalkan oleh Victor Hensen tahun 1887, yang berasal dari bahasa Yunani, "planktos", yang berarti menghanyut atau mengembara (Nontji, 2008). Plankton dapat dibagi menjadi dua golongan utama yakni phytoplankton dan zooplankton. Phytoplankton (acapkali pula disebut plankton nabati) dan zooplankton sering pula disebut plankton hewani (Nontji. 2002). Menurut Manickam et al. (2012) di saluran irigasi Parambikulam-Aliyar India menyatakan bahwa phytoplankton biasanya hadir di semua jenis air dan sangat bermanfaat bagi ekosistem tergantung pada jumlah dan keanekaragamannya. Organisme ini adalah produsen utama dari siklus makanan akuatik. Sehingga kelimpahan dan juga keanekaragaman dari plankton ini perlu mendapatkan perhatian, agar dapat terjaga
p-ISSN 1907-3089, e-ISSN 2651-5869

https://journal.uniku.ac.id/index.php/quagga

keberadaannya. Oleh karena itu keberadaan phytoplankton sangatlah diperlukan untuk keberlangsungan hidup hewan akuatik lainnya, salah satunya ikan dewa. Sesuai dengan penelitian yang dilakukan oleh Park dan Shim (2007) di pantai barat Korea bahwa komposisi phytoplankton dan zooplankton mempengaruhi populasi ikan, sehingga ikan tidak dapat hidup apabila produsennya tidak ada dan begitu juga dengan organisme perairan lainnya.

Penelitian mengenai keanekaragaman phytoplankton di Situ Balong Kambang ini dapat dijadikan sebagai bioindikator untuk mengetahui kualitas dan kesuburan air, serta mengetahui tingkat kelimpahan pakan alami ikan Dewa, dan hubungan antara keanekaragaman phytoplankton dengan parameter fisika-kimia. Satu diantara biota yang sering digunakan dalam keperluan ini adalah plankton karena studi ekologinya murah dalam biaya, mudah dalam pelaksanaan dan efektif dalam hasil yang diperoleh. Dapat dipastikan perairan yang memiliki kualitas air yang baik didalamnya terdapat beranekaragam organisme yang hidup salah satunya adalah beranekaragamnya kelompok phytoplankton yang berguna untuk kelestarian dan kelangsungan hidup organisme di dalamnya, dan tidak hanya phytoplankton namun juga baik untuk hewan air lainnya seperti ikan. Keberadaan plankton dalam suatu perairan dapat digunakan untuk mengetahui tingkat produktivitas suatu perairan. Adanya phytoplankton dapat menandakan kesetabilan suatu perairan \{(Handayani dan Patria, 2005 dalam Aidil, dkk. 2016)\}. Serta pada Bhaskar, et al 2015 di Danau Air Tawar Gogi, Distrik Yadgir, Karnataka yang merupakan perairan lentik atau tergenang, Melalui survei lapangan, terdapat dua puluh satu spesies phytoplankton dicatat di bawah empat kelas yaitu Bacillariophyceae (8), Chlorophyceae (7), Cyanophyceae (5) Charophyceae (1) dan dua belas keluarga dan Fragilariaceae (4), Bacillariaceae (3) , Zygnemataceae (3), Desmidiaceae (2), Oscillatoriaceae (2), Melosiraceae (1), Cladophoraceae (1), Scenedesmaceae (1), Microcystaceae (1), Nostocaceae (1), Phormidiaceae (1), Characeae (1) . 
Quagga: Jurnal Pendidikan dan Biologi Volume 10, Nomor 1, Januari 2018

Berdasarkan uraian di atas, permasalahan yang dikaji dalam penelitian ini adalah bagaimanakah tingkat keanekaragaman phytoplankton di Situ Balong Kambang Kabupaten Kuningan.

\section{METODOLOGI PENELITIAN}

Penelitian ini dilaksanakan di Situ Balong Kambang Desa Pasawahan Kecamatan Pasawahan Kabupaten Kuningan, Laboratorium Pendidikan Biologi Fakultas Keguruan dan Ilmu Pendidikan Universitas Kuningan. Kegiatan penelitian dilaksanakan pada bulan April - Mei 2017. Metode yang digunakan dalam penelitian ini adalah metode survei yaitu mengambil sampel dari Situ Balong Kambang. Penentuan pengambilan sampel dengan metode sampling sistematis. Dalam penelitian ini ditetapkan 5 stasiun pengukuran dan pengambilan contoh air dan plankton. Pengambilan sampel dilakukan sebanyak 3 kali tiap stasiun. Penghitungan Phytoplankton dengan menggunakan metode penyapuan menggunakan Haemocytometer. Menghitung kelimpahan ikan dewa dengan menggunakan metode kuadran. Parameter pendukung fisika adalah suhu, Intensitas cahaya dan kecepatan arus serta parameter kimia yaitu DO, BOD dan $\mathrm{pH}$.

Informasi yang perlu diketahui dari ekosistem Situ BalongKambang untuk mendapatkan gambaran kondisi situ adalah : (1) Analisis keanekaragaman menggunakan indeks keanekaragaman Sannon-Wiener dalam Odum ( 1993 ):

$\begin{array}{ll} & \mathrm{H}^{\prime}=-\sum_{i=s}^{S}\left(P_{i}\right)\left(\ln P_{i}\right) \\ \mathrm{H} & : \text { Indeks keanekaragaman } \\ \mathrm{Pi} & : \mathrm{n}_{\mathrm{i}} / \mathrm{N} \\ \mathrm{n}_{\mathrm{i}} & : \text { jumlah individu jenis ke-i } \\ \mathrm{N} & : \text { Jumlah total individu } \\ \mathrm{S} & : \text { Jumlah spesies }\end{array}$

Nilai atau kriteria keanekaragaman jenis adalah :

$\mathrm{H}^{\prime}<1=$ Keanekaragaman rendah

$1<\mathrm{H}^{\prime}<3=$ Keanekaragaman sedang

$\mathrm{H}^{\prime}>3=$ Keanekaragaman tinggi.

(2) Indeks Keseragaman jenis di analisis menggunakan indeks keseragaman Evennes dalam Odum (1993).

$\mathrm{J}^{\prime}=\frac{H^{\prime}}{\log S}$

Dimana:
p-ISSN 1907-3089, e-ISSN 2651-5869

https://journal.uniku.ac.id/index.php/quagga

$\mathbf{J}=$ Indeks Keseragaman

$\mathrm{H}^{\prime}=$ Indeks Keanekaragaman

$\mathrm{S}=$ Jumlah Spesies

Indeks Keseragaman (E) berkisar antara $0-1$

dengan kriteria sebagai berikut :

$0-0,4 \quad$ : Keseragaman jenis rendah

$0,4-0,6:$ Keseragaman jenis sedang

$0,6-1,0$ : Keseragaman jenis tinggi

(3) Indeks Dominasi dihitung berdasarkan Indeks Simpson dalam Odum ( 1993 ).

$\mathrm{D}=\sum_{i=s}^{s}\left(\frac{n_{1}}{N}\right)^{2}=\sum_{i=s}^{s}\left(P_{i}\right)^{2}$

$\mathrm{J}=$ Indeks Dominasi

$\mathrm{ni}=$ Jumlah individu ke-I

$\mathrm{N}=$ Jumlah Total Individu

Kriteria yang digunakan untuk mengetahui Indeks Dominasi tersebut adalah :

$<0,5 \quad$ : Dominasi jenis rendah

$0,5<0<1$ : Dominasi jenis sedang

$0>1 \quad$ : Dominasi jenis tinggi

(4) Indeks Kelimpahan menggunakan

rumus dari American Public

HealthAssociation \{(APHA, 1989 dalam

Yuliana, 2015)\}, yaitu :

$\mathrm{N}=\frac{O i}{O p} \times \frac{V r}{V o} \times \frac{1}{V s} \times \frac{n}{p}$

Dimana :

$\mathrm{N}=$ Jumlah individu per liter

$\mathrm{Oi}=$ Luas gelas penutup preparat $\left(\mathrm{mm}^{2}\right)$

$\mathrm{Op}=$ Luas satu lapang pandang $\left(\mathrm{mm}^{2}\right)$

$\mathrm{Vr} \quad=$ Volume air tersaring $(\mathrm{ml})$

Vo = Volume air yang diamati $(\mathrm{ml})$

Vs = Volume air yang tersaring $(\mathrm{L})$

$\mathrm{n} \quad=$ Jumlah plankton pada seluruh lapang pandang

Metode Penghitungan Populasi Ikan Dewa (Tor tambroides)

$\mathrm{D}=\frac{A \times P}{Q}$

Keterangan :

$\mathrm{D}=$ Densitas populas hewan

$\mathrm{A}=$ Luas daerah yang akan dicari

populasinya

$\mathrm{P}=$ Jumlah individu yang ditemukan pada

semua unit daerah pencuplikan

$\mathrm{Q}=$ Jumlah luas daerah cuplikan (Leksono, 2007)

Pengambilan Sampel Phytoplankton

Pengambilan sampel dilakukan di 5 stasiun. Pengambilan sampel air dilakukan secara pasif dengan menggunakan ember 5 liter sebanyak 100 liter dengan 3x pengulangan dan disaring dengan plankton 
Quagga: Jurnal Pendidikan dan Biologi Volume 10, Nomor 1, Januari 2018

net $31 \mathrm{~cm}$ dengan mata jaring berukuran $30-$ 60 mikron. Air sampel yang disaring kemudian dimasukkan ke dalam botol sampel dan di berikan label. Pengamatan sampel phytoplankton menggunakan mikroskop binokuler perbesaran 10x40. Perhitungan phytoplankton dengan menggunakan Haemocytometer dengan cara menyisir semua kotak Haemocytometer kemudian menghitung phytoplankton yang tercacah di Haemocytometer.

\section{Identifikasi Phytoplankton}

Identifikasi fitoplankton menggunakan mikroskop binokuler. Pengamatan dilakukan pada lima kotak pada masing-masing pojok yang ditentukan dan bagian tengah. yaitu pojok kiri atas, pojok kiri bawah, pojok kanak atas, pojok kanan bawah dan kotak pada bagian tengah pada haemocytometer. Dari setiap sampel diambil $1 \mathrm{ml}$ untuk diteteskan pada haemocytometer kemudian diamati di bawah mikroskop binokuler. Hasil pengamatan phytoplankton akan di identifikasi dengan menggunakan buku identifikasi dari buku Freshwater Algae Edward G. Bellinger and David C. Sigee dan situs AlgaeBase yang dapat di akses pada http://www.algaebase.org/

\section{HASIL DAN PEMBAHASAN}

Table 1. Komposisi Jenis Phytoplankton di Lima Stasiun

\begin{tabular}{|c|c|c|c|c|c|c|c|}
\hline & \multirow[b]{2}{*}{ NAMA GENUS } & \multirow{2}{*}{\multicolumn{5}{|c|}{ STASIUN }} & \\
\hline NO & & & & & & & JUMLAH \\
\hline 1 & Actinastrum & $\frac{1}{7}$ & $\frac{2}{8}$ & 3 & $\begin{array}{c}\mathbf{4} \\
19\end{array}$ & $\frac{5}{14}$ & 年 \\
\hline 2 & Amphora & 46 & 46 & 20 & 15 & 44 & 171 \\
\hline 3 & Closterium & 1 & 2 & 2 & 1 & 1 & 7 \\
\hline 4 & Coelastrum & 2 & 4 & 2 & 1 & 1 & 10 \\
\hline 5 & Cocconeis & 3 & 2 & 11 & 7 & 1 & 24 \\
\hline 6 & Gomphonema & 6 & 4 & 10 & 25 & 16 & 61 \\
\hline 7 & Stigeoclonium & 6 & 6 & 5 & 9 & 9 & 35 \\
\hline 8 & Hyalodiscus & 1 & 1 & 3 & 1 & 1 & 7 \\
\hline 9 & Desmidium & 211 & 127 & 127 & 130 & 205 & 800 \\
\hline 10 & Navicula & 236 & 89 & 45 & 37 & 50 & 457 \\
\hline 11 & Synedra & 92 & 14 & 10 & 18 & 27 & 161 \\
\hline 12 & Spyrogira & 135 & 115 & 122 & 150 & 121 & 643 \\
\hline 13 & Pediastrum & 2 & 1 & 8 & 1 & 14 & 26 \\
\hline 14 & Spirulina & 1 & 1 & 1 & 1 & 1 & 5 \\
\hline 15 & Scenedesmus & 1 & 1 & 10 & 1 & 3 & 16 \\
\hline 16 & Melosira & 121 & 143 & 55 & 98 & 157 & 574 \\
\hline 17 & Encynonema & 10 & 6 & 6 & 3 & 19 & 44 \\
\hline 18 & Gloeotrichira & 2 & 1 & 28 & 1 & 2 & 34 \\
\hline 19 & Eudorina & 1 & 1 & 5 & 1 & 1 & 9 \\
\hline 20 & Cyanosystis & 1 & 1 & 4 & 1 & 1 & 8 \\
\hline 21 & Moscocrocis & 20 & 1 & 7 & 7 & 1 & 36 \\
\hline 22 & Diatoma valgare & 23 & 12 & 19 & 12 & 35 & 101 \\
\hline 23 & $\begin{array}{l}\text { Diatoma } \\
\text { alongatum }\end{array}$ & 1 & 1 & 4 & 1 & 13 & 20 \\
\hline 24 & Cymbella & 13 & 16 & 9 & 28 & 41 & 107 \\
\hline 25 & Nitzschia capitalia & 5 & 51 & 6 & 46 & 22 & 130 \\
\hline 26 & Nitzschia scalaris & 45 & 12 & 11 & 1 & 27 & 96 \\
\hline 27 & Pinnularia & 82 & 1 & 3 & 9 & 1 & 96 \\
\hline 28 & Mougeotia & 116 & 143 & 72 & 58 & 116 & 505 \\
\hline \multirow[t]{3}{*}{29} & Aphanocapsa & 1 & 6 & 7 & 1 & 50 & 65 \\
\hline & Jumlah individu & 1191 & 816 & 623 & 683 & 994 & \\
\hline & Jumlah genus & 29 & 29 & 29 & 29 & & \\
\hline
\end{tabular}

p-ISSN 1907-3089, e-ISSN 2651-5869

https://journal.uniku.ac.id/index.php/quagga

Setelah dilakukan penelitian dan pengamatan mengenai keanekaragaman phytoplankton di Situ Balong Kambang dengan lima stasiun, menunjukan data bahwa hasil jenis phytoplankton yang di dapat dari sampel yang di amati adalah 4 divisi/phylum, 6 kelas, 18 ordo, 22 famili, 27 genus, dan 4 spesies. Adapun Filum yang ditemukan yaitu : Chlorophyta, Cynophyta, Bacillariophyta, dan Cyanobacteria. Dari divisi Chlorophyta di dapat kelas Chlorophyceae (6 genus) dan Zygnematophyceae (4 genus), sedangkan pada divisi Cynophyta didapat kelas Cyanophyceae (3 genus), pada filum Bacillariophyta di dapat kelas Bacillariophyceae (11 genus) dan Coscinodiscophyceae (1 genus), kemudian pada filum Cyanobacteria di peroleh kelas Cyanophyceae (2 genus).

Kondisi situ Balong Kambang di salah satu desa di Kabupaten Pasawahan masih tergolong produktif terbukti dengan keberadaan beberapa genus phytoplankton yang berhasil di identifikasi, namun keberhasilan dari melestarikan ikan dewa juga harus didukung dengan sistem pengelolaan lingkungan yang baik dan tepat demi keberlanjutan hidup ikan dewa. Kondisi lingkungan Balong Kambang dapat diukur dengan melihat kualitas air yang salah satunya ditentukan oleh keberadaan phytoplankton.

Table 2. Kategori tingkat Kualitas perairan menurut indeks keanekaragaman phytoplankton

\begin{tabular}{|c|c|}
\hline $\begin{array}{c}\text { Tingkat } \\
\text { Kualitas Air }\end{array}$ & $\begin{array}{c}\text { Indeks Keanekaragaman } \\
\text { Phytoplankton }\end{array}$ \\
\hline Sangat baik & $>2,00$ \\
\hline Baik & $2,60-2,00$ \\
\hline Sedang & $1,59-1,00$ \\
\hline Buruk & $1,00-1,39$ \\
\hline Sangat Buruk & $<1,00$ \\
\hline
\end{tabular}

Dari tabel 2 Canter dan Hill (1981) dalam Afihandarin (2015) menunjukan hasil penelitian di Situ Balong Kambang di peroleh nilai indeks keanekaragaman phytoplankton rata-rata dari kelima stasiun $>2,00$. Hal tersebut menunjukan bahwa kualitas air yang ada dalam situ Balong Kambang memiliki kualitas air yang sangat baik. 
Quagga: Jurnal Pendidikan dan Biologi Volume 10, Nomor 1, Januari 2018

Table 3. Hubungan Indeks Biologi Perstasiun

\begin{tabular}{|c|c|c|c|c|}
\hline Stasiun & $\begin{array}{c}\text { Indeks } \\
\text { Keanekara } \\
\text { gaman } \\
\left(\mathbf{H}^{\prime}\right)\end{array}$ & $\begin{array}{c}\text { Indeks } \\
\text { Domina } \\
\text { nsi (D) }\end{array}$ & $\begin{array}{c}\text { Indeks } \\
\text { Keseraga } \\
\text { man }(\mathbf{J})\end{array}$ & $\begin{array}{c}\text { Indeks } \\
\text { Kelimpa } \\
\text { han }\left(\mathbf{D}_{\mathbf{i}}\right)\end{array}$ \\
\hline I & 2.40 & 0.120 & 0.71 & 1191 \\
\hline II & 2.33 & 0.134 & 0.69 & 767 \\
\hline III & 2.61 & 0.116 & 0.78 & 623 \\
\hline IV & 2.42 & 0.129 & 0.72 & 683 \\
\hline V & 2.54 & 0.111 & 0.76 & 994 \\
\hline
\end{tabular}

Indeks keanearagaman phytoplankton di semua stasiun berkisar antara $2.30-2.60$ sehingga dapat dikatakan indeks keanekaragaman phytoplankton di semua stasiun termasuk dalam kategori sedang. Sesuai dengan yang diungkapkan oleh (Shannon-Wiener) dalam Odum, 1993 bahwa H' $1-3$ yaitu menunjukan indeks keanekaragaman sedang. Menurut Odum (1993) bahwa indeks keanekaragaman yang tinggi menunjukan stasiun tersebut sangat cocok dengan pertumbuhan plankton.

Indeks dominansi memperlihatkan kekayaan jenis komunitas serta keseimbangan jumlah individu setiap jenis. Indeks dominansi di semua stasiun termasuk ke dalam kategori rendah yaitu berkisar antara $0.11-0.13$, karena disetiap stasiun memiliki indeks dominansi mendekati 0 . Hal ini di perkuat oleh Pirzan, dkk. (2008) yang menyatakan bahwa apabila keseragaman mendekati nol berarti keseragaman antar spesies di dalam komunitas tergolong rendah dan sebaliknya keseragaman yang mendekati satu dapat dikatakan keseragaman antar spesies tergolong merata atau sama.

Nilai indeks keseragaman phytoplankton pada Situ Balong Kambang Desa Pasawahan memiliki nilai keseragaman stabil. Menurut Evannes dalam Odum, 1993 Kategori nilai keseragaman (e) yaitu berkisar antara $0-1$ dengan nilai yang diperoleh di Situ balong Kambang adalah 0,6 - 1,0 yang berarti Keseragaman jenis tinggi. Dari data di atas dapat di lihat bahwa Indeks Keseragaman phytoplankton berada pada kondisi stabil dimana dari semua stasiun memiliki nilai yang berkisar antara $0,69-0,78$.

Kelimpahan phytoplankton di Situ Balong Kambang pada stasiun I sebesar 1191 individu/ L, stasiun II 767 individu/ L, stasiun III 623 individu/ L, stasiun IV sebesar 683 individu/ L, dan stasiun IV 994 individu/ $\mathrm{L}$ disajikan pada Tabel 2 tergolong rendah.
p-ISSN 1907-3089, e-ISSN 2651-5869

https://journal.uniku.ac.id/index.php/quagga

Hal ini sesuai dengan pendapat Rimper (2002) dalam Efrizal (2006) di perairan pulau penyengat kota tanjung pinang provinsi kepulauan riau yang menyatakan bahwa kelimpahan phytoplankton jika $<12500 \mathrm{sel} / \mathrm{l}$ termasuk kategori rendah.

Table 4. Parameter Fisika-Kimia Hasil dari Pengukuran di Semua Stasiun

\begin{tabular}{|c|c|c|c|c|c|}
\hline $\begin{array}{c}\text { Parameter } \\
\text { Fisika- } \\
\text { Kimia }\end{array}$ & $\begin{array}{c}\text { Stasiun } \\
\text { I }\end{array}$ & $\begin{array}{c}\text { Stasiun } \\
\text { II }\end{array}$ & $\begin{array}{c}\text { Stasiun } \\
\text { III }\end{array}$ & $\begin{array}{c}\text { Stasiun } \\
\text { IV }\end{array}$ & $\begin{array}{c}\text { Stasiun } \\
\text { V }\end{array}$ \\
\hline $\begin{array}{c}\text { Kedalaman } \\
\text { (m) }\end{array}$ & 1,6 & 1,6 & 1,2 & 1,2 & 1,2 \\
\hline $\begin{array}{c}\text { Kecepatan } \\
\text { Arus (m/s) }\end{array}$ & 0,3 & 0,08 & 0,004 & 0,38 & 0,005 \\
\hline $\begin{array}{c}\text { Intensitas } \\
\text { Cahaya (lux) }\end{array}$ & 35 & 40 & 17 & 18 & 25 \\
\hline Ph & 7 & 7,3 & 7,1 & 7 & 7,2 \\
\hline DO (mg/l) & 11,7 & 10,8 & 10,8 & 11,7 & 8.8 \\
\hline BOD (ppm) & 4,3 & 2,4 & 2,6 & 3,3 & 2,7 \\
\hline Suhu ( $\left.{ }^{\circ} \mathbf{C}\right)$ & 24 & 25 & 24 & 24 & 24 \\
\hline
\end{tabular}

Saat dilakukan pengukuran berkisar antara $1,2 \mathrm{~m}-1,6 \mathrm{~m}$, kedalaman teringgi pada stasiun I dan II yaitu 1,6 m. Hal ini sesuai dengan pernyataan Odum (1993) yang mengemukakan pada umumnya beberapa jenis plankton dapat ditemukan kedalaman yang berbeda. Kedalaman perairan yang berbeda akan memberi pengaruh yang berbeda pula terhadap jenis dan kelimpahan plankton.

Kecepatan Arus di perairan Balong Kambang pada stasiun I sekitar $0,3 \mathrm{~m} / \mathrm{s}$, stasiun II $0,008 \mathrm{~m} / \mathrm{s}$, stasiun III $0,004 \mathrm{~m} / \mathrm{s}$, stasiun IV $0,38 \mathrm{~m} / \mathrm{s}$, dan stasiun V $0,005 \mathrm{~m} / \mathrm{s}$. Menurut Wijayanti (2011) dalam Pratiwi (2015) di perairan Malang Rapat Kecepatan arus dari $0,1 \mathrm{~m} / \mathrm{dtk}$ termasuk kecepatan arus yang sangat lemah, sedangkan kecepatan arus sebesar $0,1-1 \mathrm{~m} / \mathrm{dtk}$ tergolong kecepatan arus yang sedang, kecepatan arus $>1 \mathrm{~m} / \mathrm{dtk}$ tergolong kecepatan arus yang kuat. Dengan demikian kecepatan arus perairan Balong Kambang dengan hasil yang didapatkan yaitu dalam keadaan sedang.

$\mathrm{pH}$ menunjukan tingkat keasaman dan kebasaan suatu perairan. Dari semua stasiun memiliki $\mathrm{pH}$ dengan rata-rata sebesar $7-7,3$ yang berarti perairan tersebut memiliki nilai $\mathrm{pH}$ yang netral diantara stasiun I, II, III. IV dan V. Odum (1993) menambahkan bahwa perairan dengan $\mathrm{pH}$ antara 6-9 merupakan perairan dengan kesuburan tinggi dan tergolong produktif karena memiliki kisaran 
Quagga: Jurnal Pendidikan dan Biologi Volume 10, Nomor 1, Januari 2018

ph yang dapat mendorong proses pembongkaran bahan organik yang ada dalam perairan menjadi mineral- mineral yang diasimilasi oleh phytoplankton.

DO (Dissolved Oxygen) yang diperoleh di stasiun I adalah $11,7 \mathrm{mg} / \mathrm{l}$, stasiun II 10,8 $\mathrm{mg} / \mathrm{l}$, stasiun III $10,8 \mathrm{mg} / \mathrm{l}$, stasiun IV 11,7 $\mathrm{mg} / \mathrm{l}$ dan $\mathrm{V} 8,8 \mathrm{mg} / \mathrm{l}$. DO tertinggi terdapat di stasiun I dan IV dan DO terendah terdapat di stasiun V. Menurut Sastrawijaya (1991) kehidupan organisma akuatik berjalan dengan baik apabila kandungan oksigen terlarutnya minimal 5 mg/l. Barus (2004) menegaskan bahwa nilai oksigen terlarut diperairan sebaiknya berkisar antara $6,3 \mathrm{mg} / \mathrm{l}$. Semakin rendah nilai oksigen terlarut maka makin tinggi tingkat pencemaran suatu ekosistem perairan tersebut.

Phytoplankton terdistribusi berdasarkan intensitas cahaya dan suhu. Semakin tinggi intensitas cahaya semakin tinggi suhu perairan, maka proses fotosintesis phytoplankton semakin tinggi sehingga jenis phytoplankton beranekaragam.

Suhu rata-rata stasiun penelitian yang diamati yaitu $24^{\circ} \mathrm{C}$ yang masih relatif normal untuk pertumbuhan phytoplankton sehingga kebanyakan jenis phytoplankton dapat beradaptasi dengan suhu tersebut. Menurut Asih (2014) kondisi yang optimal adalah berkisar $25{ }^{\circ} \mathrm{C}$ karena pada kondisi tersebut beberapa jenis phytoplankton melakukan produktifitas optimal. Menurut Astuty (2002) dan Isdarmawan (2005) dalam Junda, dkk. (2012) menambahkan bahwa kisaran suhu yang mendukung pertumbuhan phytoplankton berkisar antara $20-30{ }^{\circ} \mathrm{C}$. Rianto, dkk. (2008) menambahkan bahwa suhu secara langsung berpengaruh dalam mengontrol laju berbagai proses metabolisme dalam sel mikroalga. Darmono (2001) menyatakan Laju proses metabolisme akan meningkat seiring dengan kenaikan suhu. Laju optimum proses metabolisme tersebut dapat dicapai pada kisaran suhu $24-31^{\circ} \mathrm{C}$.

Nilai BOD (Biochemical Oxygen Demand) adalah hasil dari $\mathrm{DO}_{0}-\mathrm{DO}_{5}$ diperoleh nilai yaitu stasiun I 4,3 mg/l, stasiun II $2,4 \mathrm{mg} / \mathrm{l}$, stasiun III $2,6 \mathrm{mg} / \mathrm{l}$, stasiun IV 3,3 $\mathrm{mg} / \mathrm{l}$ dan stasiun $\mathrm{V} 2,7 \mathrm{mg} / \mathrm{l}$. BOD tertinggi terdapat pada stasiun $\mathrm{I}$, hal tersebut menunjukan bahwa stasiun I memiliki
p-ISSN 1907-3089, e-ISSN 2651-5869

https://journal.uniku.ac.id/index.php/quagga

konsentrasi bahan organik di dalam perairan yang lebih tinggi dari stasiun lainnya.

Menurut Brower, et al,(1990) dalam Yazwar (2008) nilai konsentrasi BOD menunjukkan suatu kualitas perairan yang masih tergolong baik dimana apabila konsumsi $\mathrm{O}_{2}$ selama periode 5 hari berkisar sampai $5 \mathrm{mg} / \mathrm{l} \mathrm{O}_{2}$ maka perairan tersebut tergolong baik dan apabila konsumsi $\mathrm{O}_{2}$ berkisar antara $10 \mathrm{mg} / \mathrm{l}-20 \mathrm{mg} / \mathrm{l} \mathrm{O}_{2}$ akan menunjukkan tingkat pencemaran oleh materi organik yang tinggi dan untuk air limbah nilai BOD umumnya lebih besar dari $100 \mathrm{mg} / \mathrm{l}$.

Table 5. Hasil Analisis Uji Regresi Linear Ganda Parameter Fisika (Kecepatan Arus, Intensitas Cahaya, Suhu) Terhadap Indeks Keanekaragaman

\begin{tabular}{|c|c|c|c|c|c|c|c|}
\hline \multicolumn{2}{|c|}{ Model } & $\begin{array}{c}\text { Sum of } \\
\text { Squares }\end{array}$ & df & $\begin{array}{c}\text { Mean } \\
\text { Square }\end{array}$ & $\begin{array}{c}\text { F } \\
\text { hit }\end{array}$ & $\begin{array}{c}\text { F } \\
\text { tab }\end{array}$ & Sig. \\
\hline \multirow{2}{*}{1} & Regression & .038 & 3 & .013 & .885 & 216 & $.634^{\mathrm{b}}$ \\
\cline { 2 - 9 } & Residual & .014 & 1 & .014 & & & \\
\cline { 2 - 9 } & Total & .053 & 4 & & & & \\
\hline
\end{tabular}

a. Dependent Variable: keanekaragaman

b. Predictors: (Constant), kecepatan arus, intensitas cahaya, SUHU

Hubungan antara parameter fisika (Kecepatan Arus, Intensitas Cahaya, Suhu) dengan keanekaragaman dihitung secara analisis menggunakan uji Regresi Linier Ganda dengan menggunakan bantuan aplikasi SPSS 21 dan hasilnya dapat dilihat pada (tabel 4). Hasil uji regresi linier antara para meter fisika dengan indeks keanekaragaman menunjukan dengan hasil perhitungan (Fhit < Ftab ), F hitung sebesar 0,885 lebih kecil dari $F$ tabel sebesar 216 dengan nilai signifikan $5 \%$ sebesar 0,634. Hal ini menunjukan bahwa nilai parameter fisika tidak ada pengaruh yang signifikan terhadap phytoplankton. 
Quagga: Jurnal Pendidikan dan Biologi Volume 10, Nomor 1, Januari 2018

Table 6. Hasil Analisis Uji Regresi Linear Ganda Parameter Kimia (pH, dan BOD)

Terhadap Indeks Keanekaragaman

\begin{tabular}{|c|c|c|c|c|c|c|c|}
\hline \multicolumn{2}{|c|}{ Model } & $\begin{array}{l}\text { Sum of } \\
\text { Square }\end{array}$ & df & $\begin{array}{c}\text { Mean } \\
\text { Square }\end{array}$ & F hit & $\begin{array}{c}\text { F } \\
\text { tab }\end{array}$ & Sig. \\
\hline \multirow{2}{*}{1} & Regression & .041 & 3 & .014 & 1.14 & 19 & $.582^{\mathrm{b}}$ \\
\cline { 2 - 9 } & Residual & .012 & 1 & .012 & & & \\
\cline { 2 - 9 } & Total & .053 & 4 & & & & \\
\hline
\end{tabular}

a. Dependent Variable: keanekaragaman

b. Predictors: (Constant), PH, DO, BOD

Hubungan antara parameter kimia $(\mathrm{pH}$ dan BOD) dengan keanekaragaman dihitung secara analisis menggunakan uji Regresi Linier Ganda dengan menggunakan bantuan aplikasi SPSS 21 dan hasilnya dapat dilihat pada (tabel 4.6). Hasil uji regresi linier antara para meter kimia dengan indeks keanekaragaman menunjukan dengan hasil perhitungan (Fhit < Ftab), F hitung sebesar 1,140 lebih kecil dari $\mathrm{F}$ tabel sebesar 19 dengan nilai signifikan 5\% sebesar 0,582. Hal ini menunjukan bahwa nilai parameter kimia tidak ada pengaruh yang signifikan terhadap phytoplankton.

Table 7. Hasil Analisis Uji Regresi Linear Sederhana Kelimpahan Phytoplankton Terhadap Kelimpahan Ikan Dewa

\begin{tabular}{|c|c|c|c|c|c|c|c|}
\hline \multicolumn{2}{|c|}{ Model } & $\begin{array}{c}\text { Sum of } \\
\text { Square }\end{array}$ & df & $\begin{array}{c}\text { Mean } \\
\text { Square }\end{array}$ & F & Ftab & Sig. \\
\hline \multirow{2}{*}{1} & Regression & 40.441 & 1 & 40.441 & 4.371 & 10.1 & $.128^{\mathrm{b}}$ \\
\cline { 2 - 8 } & Residual & 27.759 & 3 & 9.253 & & & \\
\cline { 2 - 8 } & Total & 68.200 & 4 & & & & \\
\hline
\end{tabular}

a. Dependent Variable: KELIMPAHAN PHYTOPLANKTON

b. Predictors: (Constant), KELIMPAHAN IKAN DEWA

Table 8. Densitas Ikan Dewa di Semua Stasiun

\begin{tabular}{|c|c|c|c|}
\hline NO & $\begin{array}{c}\text { Stasiun } \\
\text { Penghitungan } \\
\text { Ikan Dewa } \\
\end{array}$ & $\begin{array}{c}\text { JUMLAH } \\
\text { IKAN } \\
\text { DEWA } \\
\end{array}$ & $\begin{array}{c}D= \\
\text { AxP/Q }\end{array}$ \\
\hline 1 & STASIUN 1 & 10 & 62.5 \\
\hline 2 & STASIUN 2 & 8 & 50 \\
\hline 3 & STASIUN 3 & 9 & 56.25 \\
\hline 4 & STASIUN 4 & 5 & 31.25 \\
\hline 5 & STASIUN 5 & 6 & 37.5 \\
\hline \multirow{2}{*}{\multicolumn{3}{|c|}{$\begin{array}{l}\text { JUMLAH } \\
\text { Jumlah populasi }\end{array}$}} & 237.5 \\
\hline & & & 1484.375 \\
\hline
\end{tabular}

p-ISSN 1907-3089, e-ISSN 2651-5869 https://journal.uniku.ac.id/index.php/quagga

Dari hasil analisis yang telah dilakukan mengenai nilai indeks kelimpahan phytoplankton dan ikan dewa di dapatkan hasil nilai kelimpahan phytoplankton (tabel 2) pada stasiun I sebesar 1101, stasiun II sebesar 767, stasiun III sebesar 623, stasiun IV sebesar 683, dan stasiun V sebesar 994. Dari data tersebut didapatkan Indeks Kelimpahan tertinggi terdapat pada stasiun I dan Indeks Kelimpahan terendah terdapat pada stasiun III. Sedangkan untuk nilai penghitungan Densitas ikan Dewa pada kelima stasiun (tabel 7) dengan plot kuadrant $2 \times 2$ meter di dapatan hasil stasiun I 63 ekor, stasiun II 50 ekor, stasiun III 56 ekor, stasiun IV 31 ekor, dan stasiun 538 ekor, dari data di atas terlihat bahwa nilai densitas ikan dewa tertinggi terdapat pada stasiun I.

Analisis Uji regresi linear sederhana (tabel 6) menunjukan nilai $\mathrm{F}$ hitung sebesar 4,371 dan $F$ tabel sebesar 10,1 dengan taraf signifikan 0,128 menunjukan nilai tersebut homogen dikarenakan indeks kelimpahan phytoplankton berpengaruh terhadap jumlah populasi ikan dewa. Dapat dilihat dari nilai kelimpahan phyoplankton dan nilai densitas ikan dewa yang diperoleh hasil keduanya menunjukan ada korelasi atau hubungan dimana kelimpahan phytoplankton tertinggi terdapat pada stasiun I dan densitas ikan dewa tertinggi terdapat pada stasiun I. Dengan kualitas air yang mendukung keberadaan ikan yang cukup banyak pada Stasiun I menurut Augusta dan Evi (2014) menyatakan kemungkinan kelimpahan ikan paling banyak di stasiun I disebabkan oleh perilaku ikan yang mencari makan, mencari pasangan, dan berkumpul dengan individu lain serta merespon faktor fisik lingkungannya sehingga ketika dihadapkan pada kondisi suhu tinggi ikan akan melakukan mekanisme menghindar menuju kondisi suhu yang sesuai.

\section{SIMPULAN}

Dari hasil penelitian diambil kesimpulan phytoplankton yang ditemukan di perairan Situ Balong Kambang Desa Pasawahan Kecamatan Pasawahan Kabupaten Kuningan adalah 4 divisi/filum, 6 kelas, 18 ordo, 22 famili, 27 genus. Keanekaragaman Phytoplankton di semua stasiun termasuk dalam kategori sedang dengan indeks $\left(\mathrm{H}^{\prime}>1\right)$ 
Quagga: Jurnal Pendidikan dan Biologi Volume 10, Nomor 1, Januari 2018

dan kualitas air di situ Balong Kambang tergolong sangat baik.

\section{UCAPAN TERIMAKASIH}

Penulis N.N mengucapkan terima kasih kepada bapak H.Zaenal Abidin,M.Pd dan bapak Edi Junaedi,M.Pd selaku dosen pembimbing yang telah memberi saran pada penelitian ini. Penulis juga mengucapkan terima kasih kepada bapak Kepala Desa Pasawahan yang telah memberikan kesempatan untuk melakukan penelitian di Situ Balong Kambang tersebut.

\section{REFERENSI}

Afihandarin. 2012. Keanekaragaman Komunitas Plankton di Telaga Sarangan dan Telaga Wahyu di Kabupaten Magetan Provinsi Jawa Timur. Departemen Biologi, Fakultas Sains dan Teknologi, SKRIPSI, Universitas Airlangga. [online]. Tersedia di http://repository.unair.ac.id/25628/ di akses pada 7 Januari 2017

Aidil, Muhamad, Sarong, Ali, Purnawan, Syahrul. 2016. Tingkat Kesamaan PlanktonPadaEkosistem Mangrove Pulo Sarok Kecamatan Singkil Kabupaten Aceh Singkil [Online] . Tersedia:http://jim.unsyiah.ac.id/fkp/ article/downloa/520/pdf. Diakses pada 7 februari 2017

Augusta, Tania Serezova dan Saptami Utami Evi. 2014. Analisis Hubungan Kualitas Air Terhadap Komunitas Zooplankton dan Ikan di Danau Hanjalutung. Jurnal Ilmu Hewani Tropika. Vol 3. No. 2. Hlm : 30-35. [online]. Tersedia di Laman : unkripjournal.com di akses pada 10 Juli 2017

Asih. P. 2014. Produktivitas Primer Fitoplankton di Perairan Teluk Dalam Desa Malang Rapat Bintan.SKRIPSI. UMRAH FIKP: Tanjung Pinang.

Barus, T. A., 2004 . Pengantar Limnologi Studi Tentang Ekosistem Air Daratan. Medan: USU Press.

Bhaskar, Katari., Sunil Nautiyal,. Y.D. Imran Khan,. \&L. Rajanna. 2015. A PreliminaryStudyon Phytoplankton in
p-ISSN 1907-3089, e-ISSN 2651-5869

https://journal.uniku.ac.id/index.php/quagga

Fresh Water-Lake of Gogi, Yadgir District, Karnataka. International Journal of Innovative Research in Science, Engineering and Technology. Vol. 4, Issue 4, April 2015 [online]. Tersedia: https://www.ijirset.com/upload/2015/ april/31_SA_Preliminary.pdf. di akses pada 23 Maret 2017

Efrizal, T. 2006. Hubungan Beberapa ParameterKualitasAir Dengan Kelimpahan Fitoplankton Di Perairan Pulau Penyengat Kota Tanjung Pinang Provinsi Kepulauan Riau. Lecture at Faculty of Marine Science and Fisheries. Maritim University of Raja Ali Haji Tanjungpinang. 22-30 [online]. Tersedia:Http://Riset.Umrah.Ac.Id/W pcontent/Uploads/2013/10/Hubungan -Beberapa-Parameter-Kualitas-AirDengan-Kelimpahan-FitoplanktonDi-Perairan-Pulau-Penyengat-KotaTanjung-Pinang-Provinsi-KepulauanRiau.Pdf. Di Akses pada $\quad 10$ Juli 2017

Darmono. 2001. Lingkungan Hidup Dan Pencemaran Hubungan Dengan Toksikologi Senyawa Logam. UI. Jakarta

Junda, Muhammad., Hasrah., \& Yusminah Hala. 2012. Identifikasi Genus Fitoplankton Pada Salah Satu Tambak Udang di Desa Bontomate'ne Kecamatan Segeri Kabupaten Pangkep. Jurnal Bionature, Volume 13, Nomor 2, hlm 108-115. [online]. Tersedia di http://ojs.unm.ac.id/index.php/bionatu re/artIcle/viewFile/1435/506. Di akses pada 23 Maret 2017

Manickam, N., BHAVAN, P. S., Vijayan, P., \& Sumathi, G. (2012). Phytoplankton species diversity in the Parambikulam-Aliyar Irrigational Canals (Tamil Nadu, India). Int $J$ Pharma and Bio Sci, 3, 289-300. [online]. Tersedia di http://www.ijpbs.net/download.php?d ownload_file $=$ vol3/issue $3 / \mathrm{bio} / 34$.pdf $\&$ did $=1521$. Diakses pada 7 Januari 2017 
Quagga: Jurnal Pendidikan dan Biologi

Volume 10, Nomor 1, Januari 2018

Nontji,Anugerah. 2002. Laut Nusantara. Djambatan, Jakarta

Odum, E.P., 1993, Dasar-Dasar Ekologi, Ed. III. Terjemahan T. Samingan, Gadjah Mada University Press, Yogyakarta

Park, Kwan S and Hyun Woung Shin. (2007). Studies on Phyto-and-zooplankton composition and its relation to fish productivity in a west coast fish pond ecosystem.Journal of Environmental Biology. 28(2) 415-422 (2007). [online].Tersedia:

https://pdfs.semanticscholar.org/7a07/ 6460661e32ca5db03e21f3e8459febe7 85a4.pdf. di akses pada 20 Februari 2017

Pirzan, Andi Marsambuana, dan Petrus Rani Pong Masak. 2008. Hubungan Keragaman Fitoplankton dengan Kualitas Air di Pulau Bauluang, kabupaten akalar, Sulawesi Selatan. $B$ I O D I V E R S I T A S. Volume 9, Nomor 3. Halaman: 217-221[online]. Tersedia:http://biodiversitas.mipa.uns .ac.id /D/D0903/D090314.pdf di akses pada 10 Juli 2017

Pratiwi, Esty Dewi. 2015. Hubungan Kelimpahan Plankton Terhadap Kualitas Air Di Perairan Malang Rapat Kabupaten Bintan Provinsi Kepulauan Riau. Ilmu Kelautan [online].

Tersedia: http://jurnal.umrah.ac.id/wpcontent/u ploads/gravity_forms/1ec61c9cb232a 03a96d0947c6478e525e/2015 /09/ ESTI.pdf. Di akses pada 13 Juli 2017

Rianto, R., Ariyani, A., Widyawan, A., Hendrayanti, D., Wardhana, W., Prihantini, B.W. 2008. Biodiversitas Cyanobacteria Dari Beberapa Situ/Danau Di Kawasan Jakarta-Depok-Bogor, Indonesia.
p-ISSN 1907-3089, e-ISSN 2651-5869

https://journal.uniku.ac.id/index.php/quagga

Departemen Biologi, Fakultas

Matematika Dan Ilmu

Pengetahuan Alam, Universitas Indonesia: Indonesia

Sastrawijaya, A. T. 1991. Pencemaran Lingkungan. Jakarta: Rineka cipta.

Yazwar. 2008. Kelimpahan Plankton dan kaitannya dengan kualitas air di prapatan danau toba. Tesis. USU : Medan http://repository.usu.ac.id/bitstream/h andle/123456789/5788/08E00842.pdf ;jsessionid=B740A88B0B8D7E56FC D152290CA0BE28? sequence $=1$ di akses pada 11 Juli 2017

Yuliana. 2015. Distribusi dan Struktur Komunitas Fitoplankton di Perairan Jailolo, Halmahera Barat. Jurnal Akuatika. Vol.VI.No.1 hal : 41-48. [online]. Tersedia di : http://ejournal.umm.ac.iddi akses pada 20 Februari 2017 